\title{
The Forest and the Trees
}

C oronavirus disease 2019 (COVID-19) is a multisystem disease; ${ }^{1}$ the brain is not spared, and neurologic presentations are increasingly reported. Neurologic symptoms, including headache, altered mental status, and anosmia, occur in many infected patients. $^{2}$ Pathologic findings range from white matter disease ${ }^{3}$ to encephalitis, ${ }^{4}$ with only small samples of pathologic specimens published to date. ${ }^{5}$ Thrombosis is common in critically ill patients with COVID-19, ${ }^{6}$ and vasculopathy has been described, clinically and pathologically. ${ }^{7}$ Given this widespread vascular involvement, the impact of the pandemic on stroke has been a prominent concern. ${ }^{8}$ Reports to date suggest large-vessel occlusion (LVO) stroke in unusual populations ${ }^{9}$ and friable clot with an increased propensity for clot fragmentation during thrombectomy. ${ }^{10}$

In this issue of the American Journal of Neuroradiology, these considerations are further informed by an article by John et al, ${ }^{11}$ from a large private medical center in the United Arab Emirates. The authors reviewed the experience of LVO care in patients positive for COVID-19 with stroke from March to May 2020, and compared this with a similar period in 2019. They found, in 2020, an increase in total stroke presentations and in LVOs (20 versus 44 patients, $P=.008$ ), attributed to changes in referral pathways during the pandemic in the region. Despite increasing case frequency, longer door-to-groin puncture times were seen in 2020 (68 versus 104 minutes, $P=.001$ ), caused by delays incurred by new safety protocols. A remarkably high rate of LVO in patients positive for COVID-19 with stroke was identified, 75\% of COVID-19-associated stroke presentations in this series. Reperfusion was achieved in $67 \%$ of patients positive for COVID-19 with LVO undergoing thrombectomy, with excellent groin-to-reperfusion times. Who were these patients? Typically, younger (mean age of 46 years) with a preponderance of men (93\%) who lacked traditional vascular risk factors (absent in $60 \%$ of the patients). Consistent with prior observations about prothrombotic tendencies, in this sample, a quarter of patients positive for COVID-19 with stroke had additional systemic thrombotic disease, and the burden of LVO clot and the multiplicity of vessels affected were notable. Forty percent of patients had more than a single intracranial arterial vessel affected by thrombosis or occlusion.

These results provide a snapshot of the potential impact of COVID-19 on stroke. The observational literature is growing. The study findings and similar reports ${ }^{9}$ have strong pathophysiologic plausibility. However, we must maintain appropriate caution. Beyond small sample sizes, there is the distinct risk of reporting bias in the literature available on COVID-19 and stroke. Reports of similar findings are lacking for other epicenters in China, Europe, and much of the most affected regions in the United States. This finding is surprising given the incidence reported in this and other positive samples. The additional variable of stroke geographies and stroke systems of care is also relevant. These results from Abu Dhabi compare technically very favorably with US or European centers, but stroke populations and systems of care are different, as the authors carefully highlight.

Despite these cautions, it seems likely that stroke presentations are affected directly by the virus. Perhaps this impact is as described in the available literature for particular subpopulations. What should we make of these and similar small series? These findings may have implications for prophylactic measures in patients severely affected by the virus, in whom coagulation abnormalities are widespread. ${ }^{12}$ The role of therapeutic dosing of anticoagulation or antiplatelet therapy in patients with COVID-19 prophylactically remains controversial (though clearly deep venous thrombosis prophylaxis is widely indicated). ${ }^{13}$ Venous cerebrovascular disease has also been reported, ${ }^{14}$ for which anticoagulation clearly has a role, but whether addressing thrombotic risk in patients with COVID-19 impacts arterial stroke rates is unknown. It also seems likely that in patients who are positive for COVID-19 and have an LVO, our thrombectomy expectations must evolve. These patients pose a technical challenge with possibly reduced likelihood of recanalization and the need to treat potentially more than a single circulation. These are points of conjecture currently. Are findings specific to Severe Acute Respiratory Syndrome COVID-19 or should they be expected in any systemic viral illness of this severity, and are they only prominent because of the pandemic nature of this one? This, too, is uncertain.

To understand these questions better, we need large-dataset analysis, looking at incidence rates, therapies, and outcomes. For instance, the American Heart Association/America Stroke Association Get With The Guidelines stroke campaign (https:// www.heart.org/en/professional/quality-improvement/get-withthe-guidelines/get-with-the-guidelines-stroke) collects data for hospitals treating stroke and will offer a window into this issue as data are progressively collated. This effort will be central to 
our understanding of the broader impact of COVID-19 on stroke pathophysiology, as distinct from its effect in currently reported pockets of patients.

While we may rightly debate the pathophysiology of COVID19 and stroke, there should be less debate about the impact of COVID-19 on stroke systems of care. ${ }^{15-17}$ The identified decreases in overall stroke presentations are driven largely by a decrease in presentation of patients with milder strokes. ${ }^{18}$ Severely affected patients with stroke still present for care, consistent with the findings of John, et al; ${ }^{11} 75 \%$ of acute stroke presentations in their patients with COVID-19 had LVOs. John et al further reported systems approaches in the centralization of care that led to their increased stroke and LVO numbers. Localization of expertise has already been pursued in disease epicenters ${ }^{19}$ and is acknowledged as effective in improving outcomes and using resources. ${ }^{20}$ Although not the focus of the article by John et al, the response at a systems level bears special emphasis. We may experience limitations in our ability to impact stroke in the individual patient with COVID-19. Much remains unknown and may remain unknown. It is well within our power, however, to positively influence the impact of this disease on stroke systems of care. ${ }^{21}$ This is the forest, not just the trees. Such system adaptations, when pursued thoughtfully and collaboratively, build a resilient stroke-care system to handle this pandemic, as well as other challenges in the future, despite the numerous uncertainties about stroke mechanisms.

\section{REFERENCES}

1. Mahajan A, Hirsch JA. Novel coronavirus: what neuroradiologists as citizens of the world need to know. AJNR Am J Neuroradiol 2020;41:552-54 CrossRef Medline

2. Mao L, Jin, H, Wang, M, et al. Neurological manifestations of hospitalized patients with COVID-19 in Wuhan, China: a retrospective case series study. JAMA Neurol 2020 Apr 10. [Epub ahead of print] CrossRef Medline

3. Lang M, Buch $\mathrm{K}$, Li MD, et al. Leukoencephalopathy associated with severe COVID-19 infection: sequela of hypoxemia? AJNR Am J Neuroradiol 2020 Jun 20. [Epub ahead of print] CrossRef Medline

4. Bernard-Valnet R, Pizzarotti B, Anichini A, et al. Two patients with acute meningoencephalitis concomitant with SARS-CoV-2 infection. Eur J Neurol 2020 Jun 20. [Epub ahead of print] CrossRef Medline

5. Solomon IH, Normandin E, Bhattacharyya S, et al. Neuropathological features of Covid-19. N Engl J Med 2020;383:989-92 CrossRef Medline

6. Klok FA, Kruip M, van der Meer NJ, et al. Confirmation of the high cumulative incidence of thrombotic complications in critically ill ICU patients with COVID-19: an updated analysis. Thromb Res 2020;191:148-50 CrossRef Medline
7. Varga Z, Flammer AJ, Steiger $P$, et al. Endothelial cell infection and endotheliitis in COVID-19. Lancet 2020;395:1417-18 CrossRef Medline

8. Spence JD, de Freitas GR, Pettigrew LC, et al. Mechanisms of stroke in COVID-19. Cerebrovasc Dis 2020 Jul 20. [Epub ahead of print] CrossRef Medline

9. Oxley TJ, Mocco J, Majidi S, et al. Large-vessel stroke as a presenting feature of Covid-19 in the young. N Engl J Med 2020;382:e60 CrossRef Medline

10. Wang A, Mandigo GK, Yim PD, et al. Stroke and mechanical thrombectomy in patients with COVID-19: technical observations and patient characteristics. J Neurointerv Surg 2020;12:648-53 CrossRef Medline

11. John S, Kesav P, Mifsud VA, et al. Characteristics of large-vessel occlusion associated with COVID-19 and ischemic stroke. AJNR Am J Neuroradiol 2020 Aug 27. [Epub ahead of print] CrossRefMedline

12. Bowles L, Platton S, Yartey N, et al. Lupus anticoagulant and abnormal coagulation tests in patients with Covid-19. $N$ Engl J Med 2020;383:288-90 CrossRef Medline

13. Thachil J, Tang N, Gando S, et al. ISTH interim guidance on recognition and management of coagulopathy in COVID-19. $J$ Thromb Haemost 2020;18:1023-26 CrossRef Medline

14. Cavalcanti DD, Raz E, Shapiro M, et al. Cerebral venous thrombosis associated with COVID-19. AJNR Am J Neuroradiol 2020;41:1370-76 CrossRef Medline

15. Rudilosso S, Laredo C, Vera V, et al. Acute stroke care is at risk in the era of COVID-19: experience at a comprehensive stroke center in Barcelona. Stroke 2020;51:1991-95 CrossRef Medline

16. Kansagra AP, Goyal MS, Hamilton S, et al. Collateral effect of Covid-19 on stroke evaluation in the United States. $N$ Engl J Med 2020;383:400-01 CrossRef Medline

17. Montaner J, Barragan-Prieto A, Perez-Sanchez S, et al. Break in the stroke chain of survival due to COVID-19. Stroke 2020;51:2307-14 CrossRef Medline

18. Siegler JE, Heslin ME, Thau L, et al. Falling stroke rates during COVID-19 pandemic at a comprehensive stroke center. J Stroke Cerebrovasc Dis 2020;29:104953 CrossRef Medline

19. Stefanini GG, Azzolini E, Condorelli G. Critical organizational issues for cardiologists in the COVID-19 outbreak: a frontline experience from Milan, Italy. Circulation 2020;141:1597-99 CrossRef Medline

20. Vonlanthen R, Lodge P, Barkun JS, et al. Toward a consensus on centralization in surgery. Ann Surg 2018;268:712-24 CrossRef Medline

21. Leslie-Mazwi TM, Fargen KM, Levitt M, et al. Preserving access: a review of stroke thrombectomy during the COVID-19 pandemic. AJNR Am J Neuroradiol 2020;41:1136-41 CrossRef Medline

(D)T.M. Leslie-Mazwi

Departments of Neurosurgery and Neurology

(D).A. Hirsch

Department of Radiology Massachusetts General Hospital Boston, Massachusetts 